\title{
Estimating growth of SMES using a logit model: Evidence from manufacturing companies in Italy
}

\author{
Amith Vikram Megaravallia ${ }^{*}$
}

${ }^{a}$ Doctoral Student, Department of Management Studies and Quantitative Methods, University of Naples Federico II, Italy

\begin{tabular}{|c|c|}
\hline C H R O N I C L E & A B S T R A C T \\
\hline $\begin{array}{l}\text { Article history: } \\
\text { Received: June } 1,2016 \\
\text { Received in revised format: No- } \\
\text { vember } 16,2016 \\
\text { Accepted: December } 12,2016 \\
\text { Available online: } \\
\text { December } 12,2016 \\
\text { Keywords: } \\
\text { Firm growth } \\
\text { Estimating the growth }\end{array}$ & $\begin{array}{l}\text { In this paper, an effort has been put to develop a model for estimating growth based on logit } \\
\text { regression (logit) and implemented the model to Italian manufacturing companies. Our data set } \\
\text { consists of } 8232 \text { SMEs of Italy. To estimate the growth of the firm an innovative approach that } \\
\text { considers annual statements issued the year before the accelerated growth has been considered } \\
\text { as the effective estimators of firm growth. The result of the logit showed that return on asset, } \\
\text { log (cash flow) and log (Inventory) positively affect in estimating the growth of the high growth } \\
\text { firm whereas working capital turnover times negatively affects in estimating the growth of the } \\
\text { firm. The discriminant power of the model using Receiver Operating Characteristics curve } \\
\text { shows } 72.35 \% \text {, which means the model is fair in terms of estimating the growth. }\end{array}$ \\
\hline
\end{tabular}

Financial ratios

Logit

\section{Introduction}

From the midst of the 1990s, attention towards the evaluation of gazelles has increased over the period. High-growth firms, which play significant role for the development of the national economy, are of high interest to policy makers and academicians because rapid growth is a reflection of firm success or market acceptance (Fesser \& Willard, 1990). First, our main objective is not to give an overall description of firm growth, but to know what features allow us to better distinguish between the high-growth firm and non-high growth firms. Second, our purpose is to identify the factors which are efficient indicators and estimators of corporate growth. To do so, it is very important to develop the methodology that best matches our goal (Davidson \& Wiklund, 2000), specially as to the nature of the dependent variable to use (dichotomic versus continuous), and the kind of econometric model to apply (discriminant analysis or regression analysis). Moreover, firm's high growth is understood as an excellent development in comparison with the average growth of other firms in the same industry, and not in absolute terms.

These types of firms are increasing more attention because they create a number of new jobs (Storey, 1994). In United States, for instance, these gazelles firms are responsible for generating approximately * Corresponding author.

E-mail address: amith.vikrama@gmail.com (A.V. Megaravalli) 
$70 \%$ of the jobs in the recent years (Cognetics, 2000). This could be the main reason for increasing interest in studying gazelles firms. High growth firms are considered as important stimulus to the national economy, are of high interest to policy makers and academicians because rapid growth is a reflection of firm success or market acceptance (Fesser \& Willard, 1990). From the midst of the 1990s, attention towards the evaluation of gazelles has increased over the period. The firms that are experiencing exceptional growth in a very short period of time can be considered as "gazelle" firms (Cognetics, 1994; 2000). Previous researchers focused on determining high growth firms and comparing high growth and non-high growth firm. In sum, the main contribution of the present research is the attempt to following a conventional model adopted in credit risk management to identify the estimators of firm's growth by using a logit regression procedure. Specifically, this paper follows an approach related to credit risk models based on accounting data, i.e. Z-score model Altman (1968) which forecast the probability of default through a linear combination of financial ratios that best differentiate between two a priori groups of firms: distressed and solvent firms. Financial ratios are taken out from the financial statements before the default. This is consistent with the idea that the balance sheet at time (t-1) affects the balance sheet at time $(\mathrm{t})$. The same idea is implemented here with the significant change that the analysis is extended to firm growth rather firm default. Except one work Sampagnaro, G. (2013) this approach has certainly not been employed from the perspective of firm growth evaluation. Since the seminal work of Altman (1968) on the credit scoring model.

This research can give some valuable observations for the practitioners who are interested in quickly isolating and selecting highly potential firms in terms of investment (e.g., venture capital firms). It can also curious to understand if there are financial constraints to HGFs and which are the most significant ratios to consider as estimators of firm growth.

\section{Theoretical Background}

\subsection{The law and its empirical evidence}

The result of numerous empirical studies in that firm growth decreases with size (Geroski, 1995; Caves, 1998). This represents a "stylized fact" in the view of few authors (Acs \& Audretsch, 1990) did not find positive relationship among firms growth and size and these results doubt the applicability of "Gibrat's law" because the outcome of the study reveal that growth follows a random walk approach and it not correlated with the firm size. Since the early sixties numerous empirical studies have been conducted to analyse the applicability of "Gibrat's law" (Wagner, 1994; Geroski, 1995; Sutton, 1997; Caves, 1998). Companies within a given market in the considered time interval including also the companies which do not survive (2) only for surviving companies in the regarded period; (3) only for firms large enough to reach the minimum efficient scale (MES). When differentiating firms by size, one can observe that deviations from the law become less with growing firm size (Evans, 1987; Hall, 1987). Analysing large firms, some studies cannot reject the law (Hall, 1987).

The majority of analysis was carried out with data from the manufacturing industry. Audretsch et al. (2004) examined the validity of law for the Dutch hospitality sector with the similar approaches applied in this study. Gibrat law hold good in 4 out of 15 cases for five business branches. The majority of the studies rejects the validity of the law (e.g., Wagner, 1992; Reid, 1995; Harhoff \& Woywode, 1998; Weiss, 1998; Audretsch et al., 1999). Wagner (1992) examined the law for manufacturing companies in lower Saxony in the time period from 1978 to 1989 and the outcome of the research rejects the validity of the law. This reflects that the growth process of company will take certain probabilistic approach, i.e. it is possible that firms noticing above average growth in one period will grow rapidly in the subsequent time. For Scottish micro-firms (establishment years is less than 3 years and less than 10 employees). Firm performance a random walk has a long history in economics (Gibrat, 1931; Ijiri \& Simon, 1964; Levinthal, 1991; Denrell et al., 2014). The result of numerous empirical studies in that growth of the firm reduces with size (Geroski, 1995; Caves, 1998). In the opinion of some authors (Acs \& Audretsch, 1990), the negative correlation between firm growth and size defeats the applicability of 
the law. From the beginning of 60's several studies have been conducted to test the implication of Gibrat's law (for extensive surveys see Wagner, 1994; Geroski, 1995; Sutton, 1997; Caves, 1998).

\section{Firm growth from the literature perspective}

Mason and Brown (2013) suggested that regulators and policy makers should be focused towards promoting high-growth and start-up firms. Based on the empirical study, HGF can be of any size. Whereas small companies are overrepresented in the population of HGFs, large companies can also play an important role in creating the jobs (Berr, 2008; Coad et al., 2012). Coad and Hölzl (2009) do observe some persistence in the top-tail of the growth distribution with small high-growth firms displaying negative autocorrelation, whereas large and established companies achieving smoother dynamics. Conversely, Capasso et al. (2013) Concluded that consistent outperformers are more often present among micro firms. Yet, other studies doubt the very existence of persistent high-growers. Daunfeldt and Halvarsson (2015) reported that companies experiencing strong job losses in one period are most likely to become high-growth units in the next period. The findings in Hölzl (2014) confirm that most of the high-growth firms do not replicate their high-growth performance over time, and show that the degree of persistence might also depend on upon the criterion adopted for the identification of growth for such companies. Storey (1994) provided an outline of the many aspects considered by researchers prior to 1994 and indicates that among small companies, there are six aspects of significance: company age, dimension, market, sector/ marketplaces, legal form, location and possession. Storey notices that previous researchers have revealed that age is inversely related to growth that is older companies develop more gradually than young companies. As already noted, empirical research has demonstrated that smaller firms grow at greater rather than larger firms.

Different firms' life cycles require different managerial decisions and priorities (Smith et al., 1985). A firm to achieve high growth needs to accept higher challenges and hurdles (e.g., Greiner, 1972; Shuman \& Seeger, 1986), which in turn needs revolutionary transformations that bring intense turmoil to a firm.

Many studies have upheld the fact that these high growth firm are the ones that create more jobs in the net terms (Birch et al., 1994; Littunen \& Tohmo, 2003), and this high growth is an indicator of firm's success (Fisher \& Reuber, 2003). Firm growth has been the major aspect of the study in the literature. The majority of the studies focused on testing the law and its proportionate effects which is also known as Gibrat's Law Gibrat (1931). One significant study into the determinants of high growth companies compared to marginal survival Cooper et al. (1994) showed that chances of survival and high growth were positively associated with having an advanced stage of education, greater industry-specific knowhow, and greater preliminary economical resources.

\section{Logit Growth Model}

The choice of the estimation model stems from the desire to replicate a predictive model which reflects the idea of Altman's (1968) credit-scoring models built on balance sheet data. A well-known Z-score model of Altman identified those unique characteristics of business failures are examined in order to specify and evaluate the factors which are efficient indicators and estimators of corporate distress. The empirical strategy used in the study to estimate the growth of the firm is described as follows:

For model building, a logit model is used, Logit model is employed in the research where dependent variable $(\mathrm{Y}=1)$ and independent variable $(\mathrm{Y}=0)$. In other words $\mathrm{Y}=1$ marked as High growth firms and $\mathrm{Y}=0$ marked as non-high growth firm, which rely on another non-observed variable $\mathrm{V}$ that relates to prediction variable as $\mathrm{V}=\mathrm{f}(\mathrm{x})$. The model takes on two unique values 0 and 1 . That denotes high growth firm and non-high growth firm. The model that can be fit is

$\operatorname{Pr}($ High growth firm $=1)=F\left(\beta_{0}+\beta_{1} W c t+\beta_{2} R O A+\beta_{3} L(c f)+\beta_{4}(\right.$ In $\left.)\right)$ 
where $F(t)=\frac{e^{t}}{1+e^{t}}$ is the cumulative normal distribution and $W c t$ is working capital turnover (times), Roa is Return on asset, $L$ (cf) is log cash flows, $L$ (In) log inventory. In this research Altman approach (Sampagnaro, 2013) is used is to conduct a selection, for each firm of two distinctive intervals, the first interval is characterized as moderate growth period and the second is characterized by high growth. In the present research the underlying argument encourages us to use the previous approach to conduct the selection process in identifying high-growth firms in three distinct time periods namely; 2011-2012, 2012-13 and 2013-2014. The purpose of the study is to identify unique characteristics of business growth in order to specify and evaluate the factors which are efficient indicators and estimators of corporate growth using logit model by examining the financial information of an original population of 8232 Italian manufacturing SMEs. In this research, we replicated this technique with respect to the growth of firms instead of firm's distress to this end; our first step was to identify the high growth firms and analyse in depth of the estimators which enable us to estimate the growth of the firm.

Two categories of manufacturing firms were created: HGF and NHGF. Specifically, we began our analysis by setting following criteria's:

1) We labelled as HGFs those firms that have more than $20 \%$ sales growth for two continuous years out of three years and also these firms should have the growth rate of less than $20 \%$ in the year 2010 .

2) We labelled as NGFs those firms which do not have the minimum growth rate of $20 \%$ in two consecutive years.

Finally, we included Industry and province as the dummies as extra control variables to account for specific industry effects. We tried to draw out a model able to detect the attribute features of firms and thus to recognize a set of indicators that can estimate the probability of the growth. Following a logit model, the purpose of the investigation is thus to assess whether it is possible to build a predictive model of potential firm performance which help to estimate the growth of the firms.

\subsection{Model Evaluation Approaches}

To evaluate the forecasting power of the logit model we used the following techniques:

\section{A. Model Accuracy}

Model accuracy is the most important dimension of model quality; Models can fail in two ways: either the model predicts a company as high growth when it is actually a non-high growth firm, Which means actually fails to achieve the expected growth or may be loss (Type I error). In this case, an investor may not get the return on investment as expected. This may also lead to loss of the investment. The model might also predict as non-high growth firm when it is actually high growth firm (Type II error). In this case, an investor may lose the opportunity to earn higher return on the investment. Which means the company still has the potential to growth and has the opportunity to provide higher return without any risk. Concluding from the above, a model should accurately classify high growth firm and nonhigh growth firm. Table 1 illustrates the two types of errors:

Table 1

Overview of Type of errors

\begin{tabular}{llll}
\hline & & \multicolumn{2}{c}{ Actual Model } \\
\cline { 3 - 4 } & & High growth firm & Non-High growth firm \\
\hline Actual Model & High growth firm & Correct Prediction & Type I error \\
& Non-High growth firm & Type II error & Correct Prediction \\
\hline
\end{tabular}

Table 1 shows the overview of possible error of the model, either of these errors is associated with certain costs. Therefore one should look to keep both error rates as low as possible. It should also to be noted that reducing one type of error often comes at the cost of other type increases. 


\section{B. ROC Curves}

Receiver Operating Characteristics (ROC) represents the discriminating power of the model. ROC curve is a plot of sensitivity defined as $\mathrm{P}$ (+|High growth firm) versus, 1- specifically defined as $\mathrm{P}$ (+|Non-high growth firm). The common part of ROC analysis is computing the area under the ROC curve (AUC: Area under the curve), which allows the ranking tested model is based on their accuracy. For classifying the accuracy of a diagnostic test, An AUC of 1 represents the excellent model while an AUC 0.5 represents that model is not successful in estimating the growth of the firms. Another application of ROC analysis is the sensitivity/specific plots. This projection displays both sensitivity and specify for all the possible cut-offs rates, it also allows to distinguish between type I and type ii error.

\section{Data and Measurement}

The data used in this study came from the AIDA dataset, a well-known and widely used commercial database provided by Bureau van Dijk. AIDA contains a detailed balance sheet and income statement information of firms in Italy of all sector of activity. Our empirical research is based on a sample of 8.232 SMEs of Italy, for the purpose of the study three different segments were picked randomly. The sampled firms in this category are: (a) Manufacture of other non-metallic mineral products (b) manufacture of basic metals (c) manufacture of motor vehicles, trailers and semi-trailers and manufacture of other transport equipment. The period of time covered in the study is from 2011 to 2014: this period is used to determine the high growth firms.2010: This period is the year before the rapid growth, various ratios and balance sheet data is used in order to specify and evaluate the factors which are efficient indicators and estimator of corporate growth.

\subsection{Measurement Of High Growth Firms}

High growth firm is mainly characterized as follows: (1) they are firms with a high growth (higher than $20 \%$ ) for at least two consecutive times during the time period 2011-2014; (2) They are firms should which have the growth rate of less than $20 \%$ in the year 2010; (3) firm belong to manufacturing sector (4) firms with maximum employees of 250 during 2011-2014; (5) firms with total revenue from sales and services do not exceed 50 million during 2011-2014; (6) firms with total assets not exceeding 43 million during 2011-2014. Nevertheless, the percentage of high-growth firms differs among industries for several reasons- differences in lifecycle phase, technological differences, macro-economic factors etc. We have set forth relative growth indicator:

$\triangle$ SALESIND: Difference between the percentages of sales growth of the firm throughout the period 2011-2014.

\section{Dependent Variable}

High growth frim: Our dependent variable is HGF that takes a value of 1 for firms with an annual sales growth rate higher than $20 \%$ for at least two consecutive times during 2011-2014, and value of 0 otherwise. That is, the value of the high-growth variable is 1 when sales indicator is equal or higher than 1 and 0 when it is not. There is no specific method to measure firm growth throughout a period of analysis Delmar et al. (2003). Since our source of data was based on the financial reports, we have employed sales growth, similar to the earlier study (Baum et al., 2001; Lumpkin and Dess, 2001). We have determined the sales growth by taking relative growth measure and difference between the percentages of sales growth of the firms throughout the period 2011-2014.

\section{Empirical Results}

Table 2 shows the estimation of logit results for year before the growth which 2010. Industry and province are considered as dummy variables in order to control the overall effects. The logit results shows 
the relationship several ratios and the likelihood of growth, all results are interpreted in terms of marginal effects, i.e., the impact of a unit change in the independent variable, centred around its mean, on the predicted dependent variable.

\section{Table 2}

Logit and Marginal results

\begin{tabular}{lcccc}
\hline & Logit (t-1) & \multicolumn{2}{c}{ Margins (t-1) } \\
\cline { 2 - 5 } & Coeff & $\mathrm{p}-$ value & Coeff & $\mathrm{p}-$ value \\
\hline Wct & -0.258 & $0.01^{* * *}$ & -0.066 & $0.01^{* * *}$ \\
Return on Asset & 0.011 & $0.04^{* *}$ & 0.000 & $0.04^{* *}$ \\
(Log)Cash Flow & 0.280 & $0.01^{* * *}$ & 0.007 & $0.01^{* * *}$ \\
(Log)Inventory & 0.066 & $0.00^{* * *}$ & 0.003 & $0.00^{* * *}$ \\
\hline
\end{tabular}

Pseudo $\mathrm{R}^{2} \quad 0.08$

Table 2 shows the results of logit and Marginal effects, ***Significance at 1\%, ** Significance at 5\%, * Significance at 10\%. HGF: High growth firms. Note: Marginal Effects of logit model estimated using the sample

Table 2 shows the estimate the probability of firm becoming high growth firm, after exploring 34 different variables, 4 optimum financial ratios and balance sheet items were selected as the best fit of the model as the estimators of growth. The static logit model is fitted using one year before the rapid growth of the firms. The logit model suggests that four variables are significant in estimating the growth model. The negative sign of working capital turnover times shows that an increase in this variables would lead to decrease in probability of firm becoming high growth in the subsequent year and it is statistical significant. Further, positive sign of return on asset, $\log$ (cash flow) and log (Inventory) shows that an increase in this variable would lead to increase in probability of firm becoming high growth.

The probabilities estimated by logit model can give a fair idea about the possible financial ratios which can be used as estimators of growth. A positive sign of the estimated coefficient indicate the probability of positive influence on the growth of the firm and negative marginal effect indicate that decrease in the value of financial indicator would proportionately increase the probability of firm achieving growth.

\section{Model Evaluation}

This section addresses the forecasting power of the model for the financial year $2010(\mathrm{t}-1)$, the most important question is whether the model is able to predict the growth of the firm.

\section{A. Model Accuracy}

In this section, we present the sensitivity and specificity as well as Type I and type II errors for the model estimated in this paper.

A model sensitivity describes the probability that a model classifies a firm as high growth $(+)$, given a specific threshold probability ( $\left.\mathrm{P}^{*}\right)$ when it is actually a high growth firm (D). A model's specificity is defined as the probability that model classifies the firm as non-high growth firm (-), given a specified threshold probability, when it actually a non-high growth firm $(\sim D)$.

Table 3 shows the result of classification matrix, the results are promising with an overall percentage of correctly classified prediction which is $96.66 \%$.Classification matrix also shows the particular rates of good classification of high growth firm and non-high growth firms. Further, type I (46) and type II (204). Type I error represents the misclassification of high growth firms as non-high growth firms ones. Type II error are the misclassification of non-high growth firms with that of high growth firms as per these result it can be noticed that the results is more biased towards high growth firm. 
Table 3

Type I error and Type II error (Classification Matrix)

High Growth Firms (D) Non High Growth Firm $(\sim \mathrm{D})$

Total

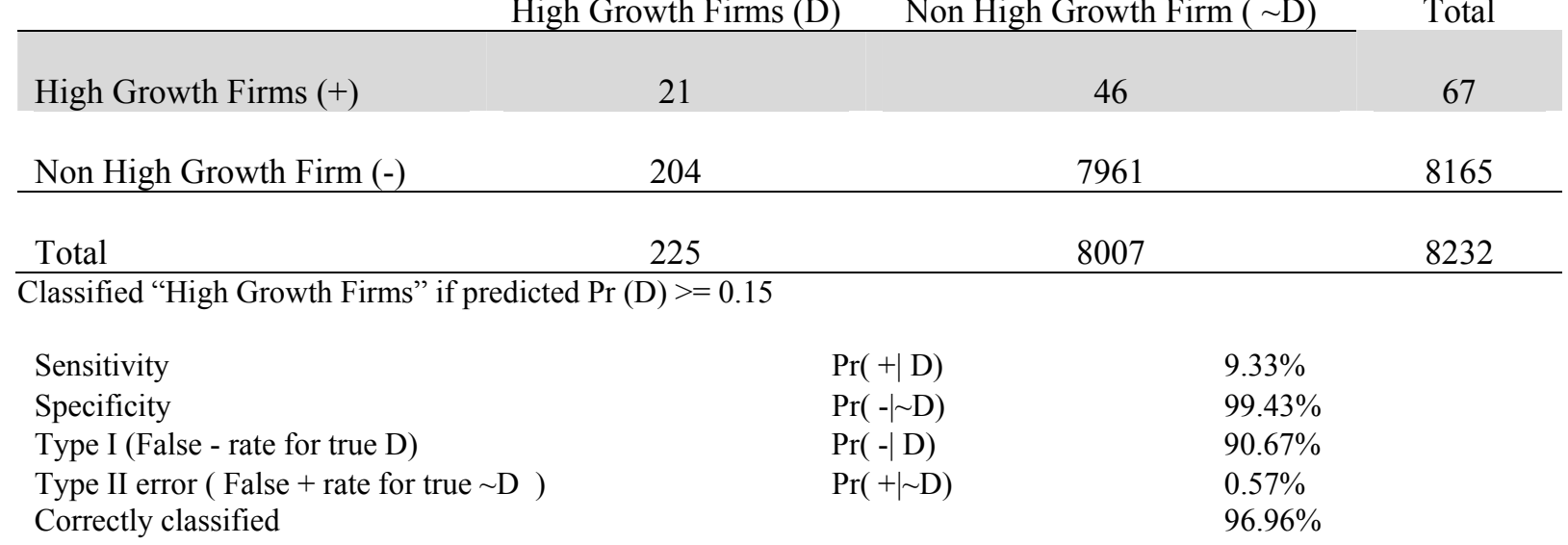

Further, Fig. 1 shows the receiver operating characteristic .The optimum model is obtained after an exploration through the ROC curve which explains the predictive power of the model. The forecasting power of the model for the financial year 2010 (t-1), the most important question is whether the model is able to predict the growth of the firm. Particularly, the ROC curves show the discriminating power of the model.

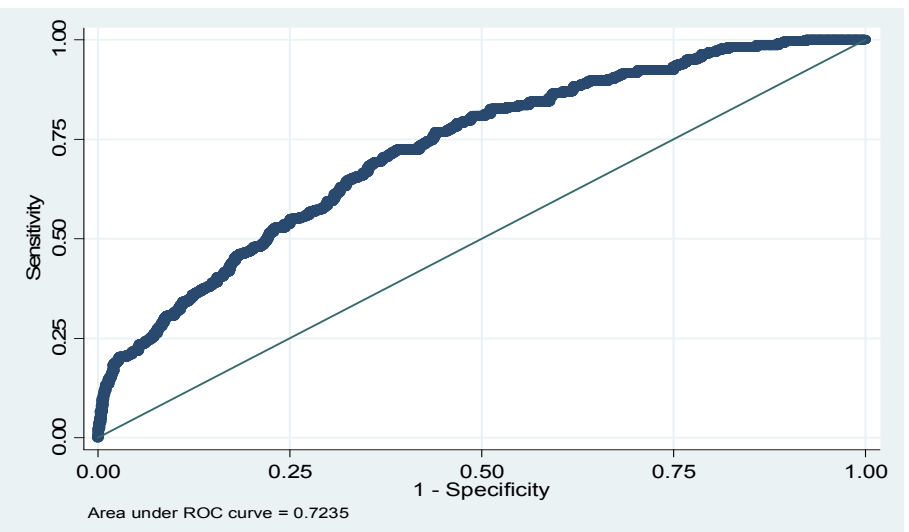

Fig. 1. ROC Curve (Model Evaluation) Source: Stata 12.0 Output

The above graph shows the ROC curves representing tests plotted in the graph. The initial step to analyse the ROC curve is to look at the area under the curve (AUC). ROC curve plots sensitivity and 1specificity and by looking at AUC as to the expected performance. Figure 2 shows that accuracy rate for the model 0.72 which is 72.35 which shows that the model is fair.

\section{Conclusion}

In this paper an effort has been put to estimate the growth of high growth firms which has been one of the most important studies in Accounting and Finance. The result obtained using Sales as the dependent variable indicated that the most important financial ratios were the Working capital turnover times (days), $\log$ (cash flow), $\log ($ Inventory) and Return on the asset. Balance sheet items like Inventory, return on asset and cash flow are also most important interns of estimating the growth of the firms. The present study gives an academic basis for future studies, in which both theoretical rigor and conceptual richness are combined, offering an integrative approach in determining high growth firm and estimating its growth using financial ratios as the estimators of growth by using (t-1) approach. However, this is an initial step for widening the research process and we believe that primary value of the study is the 
insight that future firm growth studies should focus more on recognizing the differences in various growth patterns: unidimensional and multidimensional phenomenon. In recognizing which of these growths pattern is more appropriate further study has to be done which constructs the appropriate samples and measures. The aim of this study was to arrive at high growth firms using sales as the measure of growth and choose the ratios and balance sheet items pertaining to a year before the growth and select the best model. The statistical sample included the manufacturing companies based in Italy which are restricted to four specific industries. 34 different variables were tested and finally, 4 ratios which best suits the model and also statistically significant were selected in order to implement the model. For analysing the logit model, Stata 12.0 version was used respectively. The results showed that logit model was able to predict the growth of the firm and also the discriminant power of the logit model is 72.35 which reflect the model is fair. Evaluating and estimating the growth of firms is important because it helps for the Investors, Investment banks, and Venture capital firms in order to select the best potential firms for their investment in order to earn higher profits. So, using the financial ratios to evaluate the growth of companies has been also considered by credit providers, stockholders, and financial analysts. There are forms or aspects of growth that our data did not capture. For example, the present idea can be implemented in one industry rather than many industries which may be the consistent approach, the present data involves only the Italian firms where the same idea can be implemented across different markets and industries as well. Further, future study can also focus individually on younger firms or large scale firms.

\section{References}

Altman, E. I. (1968). Financial ratios, discriminant analysis and the prediction of corporate bankruptcy. The Journal of Finance, 23(4), 589-609.

Acs, Z. J., \& Audretsch, D. B. (1990). Innovation and small firms. Mit Press.

Barringer, B. R., Jones, F. F., \& Neubaum, D. O. (2005). A quantitative content analysis of the characteristics of rapid-growth firms and their founders. Journal of Business Venturing, 20(5), 663-687.

Audretsch, D. B., \& Mahmood, T. (1994). Firm selection and industry evolution: the post-entry performance of new firms. Journal of Evolutionary Economics, 4(3), 243-260.

Audretsch, D. B., Santarelli, E., \& Vivarelli, M. (1999). Start-up size and industrial dynamics: some evidence from Italian manufacturing. International Journal of Industrial Organization, 17(7), 965-983.

Audretsch, D. B., Klomp, L., Santarelli, E., \& Thurik, A. R. (2004). Gibrat's Law: Are the services different?. Review of Industrial Organization, 24(3), 301-324.

Baum, J. R., Locke, E. A., \& Smith, K. G. (2001). A multidimensional model of venture growth. Academy of Management Journal, 44(2), 292-303.

BERR (2008). High growth firms in the UK - Lessons from an analysis of comparative UK.

Birch, D. L. (1987) Job Generation in America. The Free Press: New York

Binks, M., \& Ennew, C. (1997). The relationship between UK banks and their small business customers. Small Business Economics, 9(2), 167-178.

Birch, D. L., \& Medoff, J. (1994). —Gazelles,\| in Lewis C. Solmon and Alec R. Levenson (eds.), Labor Markets, Employment Policy and Job Creation, Boulder: Westview Press, 159-168.

Caves, R. E. (1998). Industrial organization and new findings on the turnover and mobility of firms. Journal of Economic Literature, 36(4), 1947-1982.

Capasso, M., Cefis, E., \& Sapio, A. (2013). Reconciling quantile auto regressions of firm size and variance-size scaling. Small Business Economics, 41(3), 609-632.

Chan, Y. E., Bhargava, N., \& Street, C. T. (2006). Having arrived: the homogeneity of high-growth small firms. Journal of Small Business Management, 44(3), 426-440.

Chandler, A. D. (1992). What is a firm? A historical perspective. European Economic Review, 36(2-3), 483492.

Coad, A., Daunfeldt, S. O., Hölzl, W., Johansson, D., \& Nightingale, P. (2014). High-growth firms: Introduction to the special section. Industrial and Corporate Change, 23(1), 91-112.

Coad, A., \& Broekel, T. (2012). Firm growth and productivity growth: evidence from a panel VAR. Applied Economics, 44(10), 1251-1269.

Coad, A., \& Hölzl, W. (2009). On the Autocorrelation of Growth Rates. Journal of Industry, Competition and Trade, 9(2), 139-166. 
COGNETICS (1994): Business Almanac.

COGNETICS (2000): Business Almanac

Cooper, A. C., Gimeno-Gascon, F. J., \& Woo, C. Y. (1994). Initial human and financial capital as estimators of new venture performance. Journal of Business Venturing, 9(5), 371-395.

Davidsson, P. \& Wiklund, J. (2000). Conceptual and empirical challenges in the study of firm growth. In D. Sexton \& H. Landström (Eds.), the Blackwell Handbook of Entrepreneurship (pp. 26-44). Oxford, MA: Blackwell Business.

Daunfeldt, S., and Elert, N. (2010, November, 26). When is Gibrat's Law a Law?

Delmar, F., Davidsson, P., \& Gartner, W. B. (2003). Arriving at the high-growth firm. Journal of Business Venturing, 18(2), 189-216.

Denrell, J., Fang, C., \& Liu, C. (2014). Perspective-Chance explanations in the management sciences. Organization Science, 26(3), 923-940.

Daunfeldt, S. O., \& Halvarsson, D. (2015). Are high-growth firms one-hit wonders? Evidence from Sweden. Small Business Economics, 44(2), 361-383.

Evans, D. S. (1987). The relationship between firm growth, size, and age: Estimates for 100 manufacturing industries. The Journal of industrial Economics, 35(4), 567-581.

Evans, D. S. (1987). Tests of alternative theories of firm growth. Journal of Political Economy, 95(4), 657-674

Feeser, H. R., \& Willard, G. E. (1990). Founding strategy and performance: A comparison of high and low growth high tech firms. Strategic Management Journal, 11(2), 87-98.

Fischer, Eileen, and A. Rebecca Reuber. (2003). "Support for rapid-growth firms: a comparison of the views of founders, government policymakers, and private sector resource providers." Journal of Small Business Management , $41.4,346-365$.

Gibrat, R. (1931). Les Inégalités Économiques, Paris, Sirey

Geroski, P. A. P. A. (1995). Innovation and competitive advantage. Organisation for Economic Co-operation and Development Economics Department Working Papers.

Geroski, P. (2002). The growth of firms in theory and in prattice. Competence, Governance and Entrepreneurship, 1, 168-186.

Greiner, L.E. (1972). Evolution and revolution as organizations grow. Harvard Business Review, 50(4), 37-46.

Hall, B. H. (1987). The Relationship between Firm Size and Firm Growth in the US Manufacturing Sector. The Journal of Industrial Economics, 35(4), 583-606.

Harhoff, D., Stahl, K., \& Woywode, M. (1998). Legal form, growth and exit of West German firms-empirical results for manufacturing, construction, trade and service industries. The Journal of Industrial Economics, 46(4), 453-488.

Hölzl, W. (2014). Persistence, survival, and growth: a closer look at 20 years of fast growing firms in Austria. Industrial and Corporate Change, 23(1), 199-231.

Im, K. S., Pesaran, M. H., \& Shin, Y. (2003). Testing for unit roots in heterogeneous panels. Journal of Econometrics, 115(1), 53-74.

Ijiri, Y., \& Simon, H. A. (1964). Business firm growth and size. The American Economic Review, 54(2), 77-89.

Lotti, F., Santarelli, E., \& Vivarelli, M. (2003). Does Gibrat's Law hold among young, small firms?. Journal of Evolutionary Economics, 13(3), 213-235.

Lotti, F., Santarelli, E., \& Vivarelli, M. (2009). Defending Gibrat's Law as a long-run regularity. Small Business Economics, 32(1), 31-44.

Levinthal D.A. (1991). Random walks and organizational mortality. Administrative Science Quarterly, 36 (3), 397-420.

Littunen, H., \& Tohmo, T. (2003). The high growth in new metal-based manufacturing and business service firms in Finland. Small Business Economics, 21(2), 187-200.

Lumpkin, G. T., \& Dess, G. G. (2001). Linking two dimensions of entrepreneurial orientation to firm performance: The moderating role of environment and industry life cycle. Journal of Business Venturing, 16(5), 429-451.

Mason, C., \& Brown, R. (2013). Creating good public policy to support high-growth firms. Small Business Economics, 40(2), 211-225.

Reid, G. C. (1995). Early life-cycle behaviour of micro-firms in Scotland. Small Business Economics, 7(2), 8995.

Sampagnaro, G. (2013), G. (2013). Estimating rapid-growth SMEs through a reversal of credit-scoring principles. International Journal of Entrepreneurship and Small Business, 18(3), 313.

Shuman, J. C., \& Seeger, J. A. (1986). The theory and practice of strategic management in smaller rapid growth firms. American Journal of Small Business, 11(1), 7-18. 
Siegel, R., Siegel, E., \& Macmillan, I. C. (1993). Characteristics distinguishing high-growth ventures. Journal of business Venturing, 8(2), 169-180.

Smith, K. G., Mitchell, T. R., \& Summer, C. E. (1985). Top level management priorities in different stages of the organizational life cycle. Academy of management Journal, 28(4), 799-820.

Storey, D. J. (1994). Understanding the Small Business Sector. Thomson Learning EMEA.

Sutton, J. (1997). Gibrat's legacy. Journal of Economic Literature, 35(1), 40-59.

Wagner, J. (1992). Firm size, firm growth, and persistence of chance: Testing GIBRAT's law with establishment data from Lower Saxony, 1978-1989. Small Business Economics, 4(2), 125-131

Wagner, J. (1994). Small firm entry in manufacturing industries: Lower Saxony, 1979-1989. Small Business Economics, 6(3), 211-223.

Weiss, C. R. (1998). Size, growth, and survival in the upper Austrian farm sector. Small Business Economics, 10(4), 305-312.

Wagner, J. (1992). Firm size, firm growth, and persistence of chance: Testing GIBRAT's law with establishment data from Lower Saxony, 1978-1989. Small Business Economics, 4(2), 125-131.

Wagner, J. (1994). The post-entry performance of new small firms in German manufacturing industries. The Journal of Industrial Economics, 42(2), 141-154.

\section{Appendix}

Table A1

List of Industry Code and Industry Description (Source : Aida, Bureau Van Dijk)

\begin{tabular}{cl}
\hline Code & \\
\hline 16 & $\begin{array}{l}\text { Manufacture of wood and of products of wood and cork, except furniture; manufacture of articles of straw } \\
\text { and plaiting materials }\end{array}$ \\
23 & Manufacture of other non-metallic mineral products \\
24 & Manufacture of basic metals \\
25 & Manufacture of fabricated metal products, except machinery and equipment \\
28 & Manufacture of machinery and equipment \\
\hline
\end{tabular}

Table A2

List of Variables Tested in the study to find the optimal model (Source:Aida, Bureau Van Dijk)

\begin{tabular}{|c|c|c|c|}
\hline Sl.No & Variables & S1.No & \\
\hline 1 & Total Fixed Assets & 19 & Cash Flow \\
\hline 2 & Total Intangible Fixed Assets & 20 & Return on asset \\
\hline 3 & Total Tangible Fixed Assets & 21 & Return on equity \\
\hline 4 & Total Financial Fixed Assets & 22 & Turnover per employee \\
\hline 5 & Research and Developments Expenses & 23 & EBITDA \\
\hline 6 & Total Current Assets & 24 & Total Inventories \\
\hline 7 & Total Receivables & 25 & Cash and cash equivalent \\
\hline 8 & Net Financial Position & 26 & Revaluation of reserves \\
\hline 9 & Total Liquid Funds & 27 & Due to banks \\
\hline 10 & Liquidity ratio & 28 & Gross Profit \\
\hline 11 & Retained earnings & 29 & Net Profit \\
\hline 12 & Total Payables & 30 & Working capital turnover \\
\hline 13 & Leverage & 31 & Return on Investment \\
\hline 14 & Coverage of fixed assets & 32 & Return on Sales \\
\hline 15 & Cost of debit & 33 & Operating cash flow \\
\hline 16 & Debt/equity & 34 & Cash conversion cycle \\
\hline 17 & Debt/EBITDA & & \\
\hline 18 & Total assets & & \\
\hline
\end{tabular}

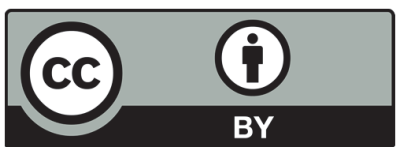

(C) 2017 by the authors; licensee Growing Science, Canada. This is an open access article distributed under the terms and conditions of the Creative Commons Attribution (CC-BY) license (http://creativecommons.org/licenses/by/4.0/). 